\title{
DNA barcoding of a stowaway reef coral in the international aquarium trade results in a new distribution record
}

\author{
Bert W. Hoeksema ${ }^{1,2,3} \cdot$ Roberto Arrigoni ${ }^{4,5}$
}

Received: 23 January 2020 / Revised: 2 April 2020 / Accepted: 15 April 2020/Published online: 27 May 2020

(C) The Author(s) 2020

\begin{abstract}
Dead corals and limestone boulders that act as substrate for live specimens of marine invertebrates and algae are sold as 'live rock' in the international aquarium trade. During a customs inspection of an airfreight shipment of 'live rock' at Schiphol Airport (Netherlands), 450 boulders imported from Indonesia were checked for the presence of undeclared organisms. During unpacking, about $50 \%$ of the boulders appeared to have small stony corals attached to them. Some of these corals belonged to a species unknown from Indonesia. Mitochondrial COI and nuclear ITS markers revealed $100 \%$ and $99.3 \%$ match with Polycyathus chaishanensis Lin et al., 2012, a species reported from tidal pools in Taiwan. This new distribution record suggests that despite their easy access, intertidal and shallow subtidal reef coral assemblages $(<1 \mathrm{~m}$ depth) may still be underexplored.
\end{abstract}

Keywords CITES $\cdot$ Customs $\cdot$ Barcoding $\cdot$ COI $\cdot$ ITS $\cdot$ Geographical distribution $\cdot$ Indonesia $\cdot$ Polycyathus $\cdot$ Reef flat $\cdot$ Intertidal

\section{Introduction}

Tropical sea aquariums are important attractions in zoos around the world but are also kept at homes by numerous hobby aquarists. Consequently, there is a high global demand for ornamental reef fishes and invertebrates in the international aquarium trade (Dee et al. 2014). To mimic coral reef environments, large pieces of coral rock and limestone boulders are mined from coral reef areas and placed in aquariums as

Communicated by C. Buschbaum

Electronic supplementary material The online version of this article (https://doi.org/10.1007/s12526-020-01075-7) contains supplementary material, which is available to authorized users.

Bert W. Hoeksema

bert.hoeksema@naturalis.nl

1 Taxonomy and Systematics Group, Naturalis Biodiversity Center, Leiden, The Netherlands

2 Groningen Institute for Evolutionary Life Sciences, University of Groningen, Groningen, The Netherlands

3 Institute of Biology Leiden, Leiden University, Leiden, The Netherlands

4 Department of Biology and Evolution of Marine Organisms (BEOM), Stazione Zoologica Anton Dohrn Napoli, Villa Comunale, 80121 Naples, Italy

5 European Commission, Joint Research Centre (JRC), Ispra, Italy decoration and substrate (Padilla and Williams 2004). They are also known to clean sea water in aquaria (Yuen et al. 2009; $\mathrm{Li}$ et al. 2017). These boulders are most easily collected from shallow water and reef flats, which can be done by local villagers (Dawson Shepherd et al. 1992; Lovell 2001; Caras and Pasternak 2009). The boulders need to be inhabited and covered by live animals and plants from natural reef environments to serve as artificial reef habitats and are therefore called 'live rock' (Best 1997; Wood et al. 2012). These live organisms may belong to encrusting species of bryozoans, calcareous algae, sponges, zoantharians, corals, and other invertebrates that hide in crevices and borings or crawl over the rock surface, such as crustaceans, molluscs, echinoderms, and worms (Parks et al. 2003; Simões et al. 2017). According to CITES regulations (Convention on International Trade in Endangered Species of Wild Fauna and Flora), such attached specimens should not belong to coral species without proper export and import permits that mention their identity (Best 1997).

There is an extensive international trade in these 'live rocks'. They originally used to be exported from tropical countries like Fiji, Indonesia, and the Philippines, while the USA trade could get supplies from Florida and Hawaii (Bruckner 2001; Lovell 2001; Parks et al. 2003; Rhyne et al. 2009; Wood et al. 2012). In the last two decades, additional exporting countries have been recorded, such as Australia, Brazil, Cuba, Haiti, Palau, Samoa, Tonga, Vanuatu, and Vietnam, indicating that the harvesting of 'live rock' has been widespread due to an increasing economic demand (Table 1; Harriott 2001; Wabnitz et al. 2003; 
Gasparini et al. 2005; Rhyne et al. 2012; Gurjão and Lotufo 2018). Because organisms dwelling on 'live rock' are kept alive when they are transported over large distances, they can form a threat as potential invasive species in new areas (Padilla and Williams 2004; Bolton and Graham 2006; Walters et al. 2006; Morrisey et al. 2011) or as pest species in their new aquarium habitats (Rhyne et al. 2004; Calado and Narciso 2005).

To examine if such attached organisms belong to alien species, DNA barcoding (Hebert et al. 2003) can be applied for their identification (Wehr 2017; Vranken et al. 2018). This method represents a fast, simple, and economic tool to identify organisms based on DNA sequences and has been successfully used, for example, for the discovery of illegal trade and alien species of marine taxa (Collins et al. 2012; Bunholi et al. 2018). It can also be used to check whether imported organisms or products made from them, belong to species that are protected under CITES (Staats et al. 2016). The present study reports on the application of DNA-barcoding methodology to assist in the identification of scleractinian corals from Indonesia that were accidentally imported in the Netherlands.

\section{Material and methods}

During a customs inspection of an airfreight shipment of 'live rock' at Schiphol Airport (The Netherlands) on 22 October 2012, 450 imported coral boulders from Indonesia were checked for the presence of undeclared organisms (Fig. 1, ESM Figs. S1-S6). According to the accompanying documents, the shipment consisted of 80 boxes and had a weight of $4050 \mathrm{~kg}$ and a total value of USD 10,600 (including freight costs). The boulders (declared as "natural stone" and "substrate/unidentified scleractinians") were kept in moist condition inside styrofoam containers, which were packed in cardboard boxes. The packaging was done 2 days before arrival.

During unpacking, approximately $50 \%$ of the boulders appeared to have small scleractinian corals attached to them (Fig. 1). Some corals belonged to a species unknown from Indonesia, and one of these (Fig. 1b, c), with a colony diameter of $2.8 \mathrm{~cm}$, was sampled and subjected to DNA barcoding for species identification. In detail, DNA extraction was carried out in the molecular laboratory of Naturalis with the DNeasy Blood and Tissue kit (Qiagen Inc., Hilden, Germany). Two loci were selected for DNA barcoding, a portion of the mitochondrial cytochrome $c$ oxidase subunit I (COI, partially) and a selection of nuclear rDNA (ITS, including the entire ITS1, 5.8S, ITS2, and a fragment of $18 \mathrm{~S}$ and $28 \mathrm{~S})$. COI was amplified using primers fungCOIforl ( $5^{\prime}$-CTG CTC TTA GTA TGC TTG TA-3') and fungCOIrev2 ( $5^{\prime}$-TTG CAC CCG CTA ATA CAG-3') (Gittenberger et al. 2011), and ITS using primers ITS4 (5'-TCC TCC GCT TAT TGA TAT GC-3') (White et al. 1990) and A18S (5'-GAT CGA ACG GTT TAG TGA GG-3') (Takabayashi et al. 1998).
Amplifications were performed in a $12.5-\mathrm{mL}$ PCR reaction mix containing $0.2 \mathrm{mM}$ of each primer, $2 \mathrm{X}$ Multiplex PCR Master Mix (Qiagen Inc., Hilden, Germany) and $<0.1$ ng of DNA. The thermal cycler profile was of $95{ }^{\circ} \mathrm{C}$ for $15 \mathrm{~min}$, 30 cycles of $95{ }^{\circ} \mathrm{C}$ for $1 \mathrm{~min}, 53{ }^{\circ} \mathrm{C}$ for $1 \min \left(50^{\circ} \mathrm{C}\right.$ for ITS), $72{ }^{\circ} \mathrm{C}$ for $1 \mathrm{~min}$, with a final phase of $72{ }^{\circ} \mathrm{C}$ for $5 \mathrm{~min}$. PCR products were directly sequenced in forward and reverse directions using an automated 3730xl DNA Analyzer (Applied Biosystem, Foster City, CA, USA). Newly obtained COI and ITS sequences from the analysed specimen were checked via Blast searches against nr GenBank database. Subsequently, they were aligned with closely related coral sequences available in GenBank using MAFFT (Katoh and Standley 2013) and the iterative refinement method E-INS-i. The phylogenetic trees were obtained using maximum likelihood criterion using RAxML (Stamatakis 2014) with a multiparametric bootstrap analysis of 500 bootstrap replicates. Newly obtained sequences of COI and ITS were deposited in NCBI under the accession numbers MN533979 and MN527240, respectively.

To keep the specimen available for future research, it has been deposited in the scientific reference collection of Naturalis Biodiversity Centre (Leiden, the Netherlands) with catalogue number RMNH.COEL.42435).

\section{Results and discussion}

Most corals attached to the imported 'live rock' could easily be identified to genus or species level, such as Coeloseris mayeri Vaughan, 1918 and Pavona sp. (both Agariciidae), Cyphastrea sp. and Merulina sp. (both Merulinidae), Montipora sp. (Acroporidae), Psammocora sp. (Psammocoridae), and Porites sp. and Stylaraea punctata (Linnaeus, 1758), both Poritidae. Stylaraea punctata is typical for shallow, intertidal areas (Kitano et al. 2014; Richards et al. 2015), and widespread in Indonesia (Hoeksema 2004).

One species in the investigated shipment was unknown for Indonesia and needed further analysis for its identification. The soft tissue of this coral showed a brown colour (Fig. 1b-d), suggesting that it is zooxanthellate. The thecae of the tubular calices were almost completely covered by encrusting coralline algae (Fig. 1d). Its corallum shape agreed with that of Polycyathus Duncan, 1876 (Caryophylliidae), a genus of 19 recognized species worldwide (Hoeksema and Cairns 2018). Many of these species are exclusively known from deep water, and therefore, all of them are usually considered as azooxanthellate corals (e.g., Cairns et al. 1999; Cairns and Kitahara 2012).

COI and ITS markers revealed a $100 \%$ and $99.3 \%$ match with specimens of Polycyathus chaishanensis Lin et al., 2012 (ESM Figs. S7-S8) collected from its type locality in Taiwan (Lin et al. 2011, 2012). So far, this species has only been recorded from here and two other localities in Taiwan, each 

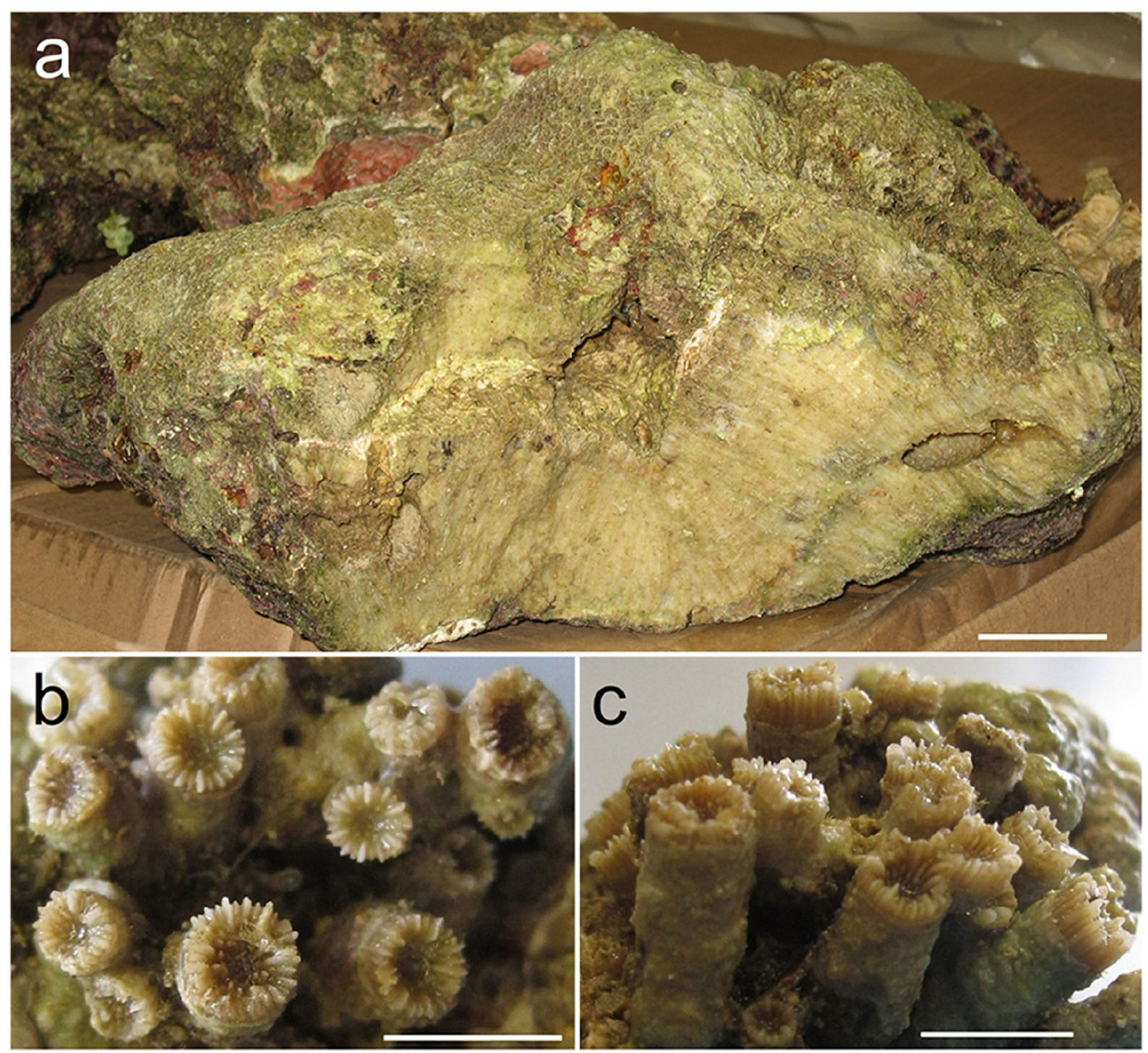

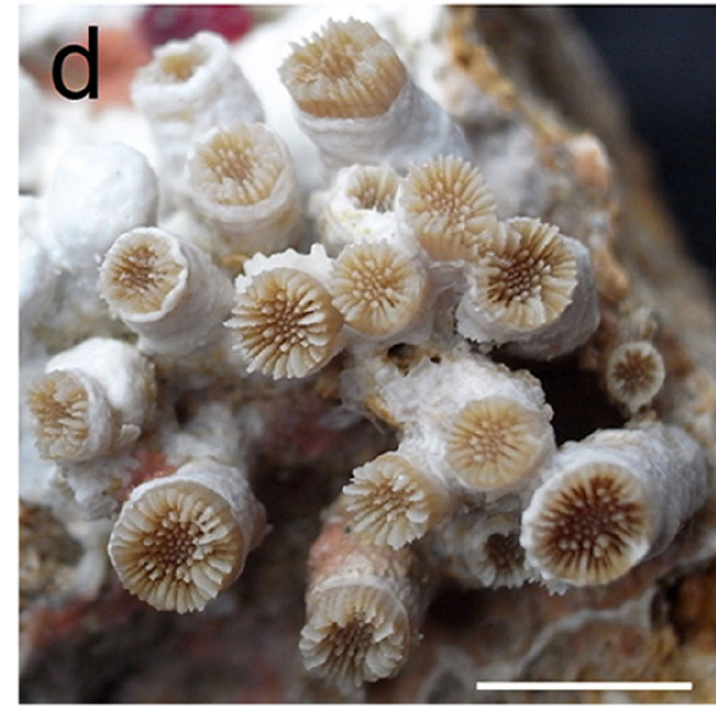

Fig. 1 a Dead coral boulder shipped as 'live rock', subject to customs inspection at Schiphol Airport (scale bar: $5 \mathrm{~cm}$ ); b, $\mathbf{c}$ Live specimen of Polycyathus chaishanensis: polyps seen from above (b) and aside (c); d, e

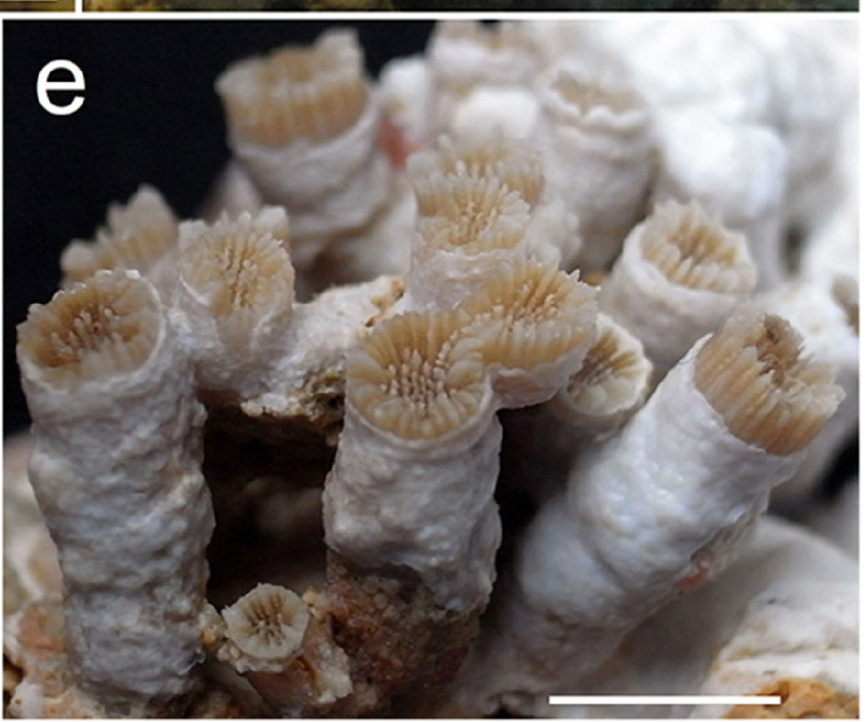

Skeleton of the same specimen after cleaning in household bleach; polyps seen from above (d) and aside (e); catalogue nr. RMNH.COEL.42435. Scale bars b-d, $5 \mathrm{~mm}$ 
time in shallow water from intertidal to $3 \mathrm{~m}$ depth (Kuo et al. 2019). The phylogenetic analyses based on both COI and ITS loci showed that our newly obtained sequences clustered together with sequences of $P$. chaishanensis from Taiwan with high bootstrap values (100 for both analyses). Moreover, the three sequences of $P$. chaishanensis from Taiwan formed a single lineage with low-moderate bootstrap value (63) in the ITS tree. Therefore, the high value of genetic identity based on Blast searches and the results from the phylogeny reconstructions seem to suggest that our specimen can be identified as $P$. chaishanensis based on the few molecular data that are actually available. Nevertheless, since molecular information on other Polycyathus species has not yet been published, we suggest the inclusion of more sequences of shallow-water species ascribed to this genus from different localities to get a more complete geographic and taxonomic sampling of this genus for future genetic analyses.

Morphological characters were also studied. The specimen from Indonesia showed calices that are 2.5-3.5 mm wide, with 24-32 septa divided over three to four cycli and a length of $1 \mathrm{~cm}$ (Fig. 1b-e). According to its original description, $P$. chaishanensis shows a maximum calice diameter of $3.7 \mathrm{~mm}$ and up to 34 septa in up to four cycli (Lin et al. 2012). Morphologically, it resembles P. hodgsoni Verheij and Best, 1987, which has been recorded from caves at depths over $35 \mathrm{~m}$ in the Philippines and the Maldives (Verheij and Best 1987). This species has smaller and shorter calices (2-3 mm in diameter, $<5$ mm long) with 20-24 septa divided over three cycli. Other Polycyathus species reported from the central Indo-Pacific have calices that are over $5 \mathrm{~mm}$ in diameter: $P$. fulvus Wijsman-Best, 1970 , known from very shallow water (0.3-0.5 m depth) in New Caledonia (Wijsman-Best 1970); P. isabela Wells, 1982 from 14 $\mathrm{m}$ depth at Galápagos (Wells 1982); P. furanaenis Verheij \& Best, 1987 found in caves at 6-52 m depth (Verheij and Best 1987); P. marigondoni Verheij \& Best, 1987, which has been found in a cave at $35 \mathrm{~m}$ depth (Verheij and Best 1987); P. andamanensis Alcock, 1893, known from dredges at unknown depths; and P. octoplus Cairns, 1999, dredged from 110 to $441 \mathrm{~m}$ depth. With regard to the environment, only $P$. fulvus with larger polyps appears to share a similar habitat with $P$. chaishanensis. To obtain a better overview of Polycyathus species, it appears that this genus is in need of a worldwide taxonomic revision, in which molecular, morphological, biogeographic, and bathymetric characteristics are taken into account. It is also important to photograph fresh specimens or examine specimens stored in ethanol to verify whether zooxanthellae are present or not, because for collected specimens, it is usually assumed that they are azooxanthellate, as in the case of Polycyathus fuscomarginatus (Klunzinger, 1879) trawled from 10 to $30 \mathrm{~m}$ depth off Chennai, Southern India (Venkataraman 2007).

The question arises whether more distribution records of rarely known coral species can be obtained from customs inspections. Large quantities of 'live rock' (mostly from Indonesia) are imported in the Netherlands (Table 1), whereas the total export of 'live rock' from Indonesia to other countries in 2012 (the year of the present example) was almost $10^{6} \mathrm{~kg}$ (Table 2). How frequently shipments of 'live rock' are being inspected by customs officers is not known. Since the imported rocks only need to be inspected for the presence of CITESlisted species at high taxonomic level (mostly Scleractinia spp.), assistance given by a coral taxonomist may not be necessary in this case. On the other hand, the present study can serve as a test case for illustrating the usefulness of DNA barcoding in the identification of protected species or their products, like previously applied to cacti (Gathier et al. 2013), medicinal plants (Eurlings et al. 2013), sharks (Liu et al. 2013; Feitosa et al. 2018), orchids (de Boer et al. 2017), and trees (Yu et al. 2017). Therefore, knowledge on the trafficking of rarely known species in the aquarium trade may benefit from more inspections assisted by expert taxonomists who can select the specimens to be used for DNA barcoding.

It is indeed remarkable that $P$. chaishanensis has not been reported from other localities despite its occurrence in shallow tidal pools and reef flats, as reported from Taiwan (Lin et al. 2012; Kuo et al. 2019). This scarcity of records suggests that shallow reef habitats in the tropics, despite their easy access, could be understudied and may house more infrequently observed species. Because most coral researchers use SCUBA equipment at depths over $3 \mathrm{~m}$, they may overlook coral species occurring in intertidal and shallow subtidal habitats ( $<1 \mathrm{~m}$ depth), such as Stylaraea punctata (Linnaeus, 1758) at Guam, which can easily be found in tidal pools on reef flats during low tide (Randall and Myers 1983; Golbuu and Richmond 2007; BWH pers. obs.). Another example is the free-living morphotype of the scleractinian coral Favia gravida Verrill, 1868, which is only known from rocky tide pools of Ascension Island (Hoeksema 2012; Hoeksema

Table 1 Import of 'live rock' $(\mathrm{kg})$ in the Netherlands from various countries over the years 2009-2018 (CITES 2020)

\begin{tabular}{lrrrrr}
\hline Year & \multicolumn{2}{l}{ Import $(\mathrm{kg})$} & & \\
\cline { 2 - 6 } & Cuba & \multicolumn{1}{c}{ Fiji } & Indonesia & Vanuatu & Vietnam \\
\hline 2009 & & 2800 & 15,000 & & \\
2010 & & 2600 & 5500 & & \\
2011 & 1000 & 2800 & 23,100 & & \\
2012 & 3000 & 3100 & 38,300 & & 300 \\
2013 & 16,500 & 19,000 & 35,700 & & 200 \\
2014 & 3800 & 5900 & 46,800 & & 600 \\
2015 & & 3500 & 38,900 & & \\
2016 & & 35,000 & 33,300 & 16,000 & \\
2017 & & 300 & 32,600 & 13,800 & \\
2018 & 14,000 & & 10,200 & & \\
\hline
\end{tabular}


Table 2 Import of 'live rock' in various countries from Indonesia in 2012 ; $*$ based on export data from Indonesia (CITES 2020)

\begin{tabular}{|c|c|}
\hline Year & Import $(\mathrm{kg})$ \\
\hline Austria & 7300 \\
\hline Belgium & 8200 \\
\hline Canada* & 53,900 \\
\hline Czechia & 1200 \\
\hline Denmark & 1600 \\
\hline Finland & 1700 \\
\hline France & 66,900 \\
\hline Germany & 101,900 \\
\hline Greece* & 2600 \\
\hline Honk Kong & 3200 \\
\hline Israel* & 3000 \\
\hline Italy & 18,400 \\
\hline Japan & 73,000 \\
\hline Korea & 19,000 \\
\hline Mexico & 3800 \\
\hline Netherlands & 38,300 \\
\hline New Zealand & 700 \\
\hline Norway & 1000 \\
\hline Poland & 15,100 \\
\hline Portugal & 800 \\
\hline Russia* & 26,500 \\
\hline Saudi Arabia* & 300 \\
\hline Spain & 8200 \\
\hline South Africa & 1000 \\
\hline Sweden* & 12,000 \\
\hline Switzerland & 3000 \\
\hline Taiwan* & 3200 \\
\hline United Arabian Emirates & 11,900 \\
\hline UK & 78,900 \\
\hline USA & 357,300 \\
\hline Total & 923,900 \\
\hline
\end{tabular}

and Wirtz 2013). These observations suggest that shallow reef environments can harbour unique coral reef fauna and that future surveys here may result in new species records.

\begin{abstract}
Acknowledgements We thank Dutch customs officers and Ate Cohen (Naturalis) for assistance at Schiphol Airport during inspection of the shipment of 'live rock', Aline Nieman (Naturalis) for assistance with the lab work, and Francesca Benzoni (KAUST) for her constructive comments on an earlier version of the ms. We are also grateful to two anonymous reviewers for their helpful remarks. The views expressed are purely those of the authors and may, with regard to RA, not in any circumstance be regarded as stating an official position of the European Commission.
\end{abstract}

\section{Compliance with ethical standards}

Conflict of interest The authors declare that they have no conflict of interest.
Ethical approval No animal testing was performed during this study.

Sampling and field studies All necessary permits for sampling were obtained by the authors from relevant authorities and are mentioned in the acknowledgements when applicable.

Authors' contribution BWH collected the examined specimen at Schiphol Airport. Both authors wrote the manuscript. BWH studied morphological characters. AR performed the molecular analysis. Both authors read and approved the manuscript.

Open Access This article is licensed under a Creative Commons Attribution 4.0 International License, which permits use, sharing, adaptation, distribution and reproduction in any medium or format, as long as you give appropriate credit to the original author(s) and the source, provide a link to the Creative Commons licence, and indicate if changes were made. The images or other third party material in this article are included in the article's Creative Commons licence, unless indicated otherwise in a credit line to the material. If material is not included in the article's Creative Commons licence and your intended use is not permitted by statutory regulation or exceeds the permitted use, you will need to obtain permission directly from the copyright holder. To view a copy of this licence, visit http://creativecommons.org/licenses/by/4.0/.

\section{References}

Alcock A (1893) On some newly-recorded corals from the Indian Seas. J Asiat Soc Bengal (Nat Hist) 62:138-149

Best MB (1997) Trade in corals and living stones. In: den Hartog JC (ed) Proceedings of the $6^{\text {th }}$ International Conference on Coelenterate Biology, Noordwijkerhout, 1995. Nationaal Natuurhistorisch Museum, Leiden, pp 47-52

Bolton TF, Graham WM (2006) Jellyfish on the rocks: bioinvasion threat of the international trade in aquarium live rock. Biol Invasions 8: $651-653$

Bruckner AW (2001) Tracking the trade in ornamental coral reef organisms: the importance of CITES and its limitations. Aquar Sci Conserv 3:79-94

Bunholi IV, da Silva Ferrette BL, De Biasi JB, de Oliveira MC, Rotundo MM, Oliveira C, Foresti F, Mendonça FF (2018) The fishing and illegal trade of the angelshark: DNA barcoding against misleading identifications. Fish Res 206:193-197

Cairns SD (1999) Cnidaria Anthozoa: deep-water azooxanthellate Scleractinia from Vanuatu, and Wallis and Futuna Islands. In: Crosnier A (ed) Résultats des Campagnes MUSORSTOM 20. Mém Mus Natl Hist Nat Sér A Zool 180:31-167

Cairns SD, Kitahara MV (2012) An illustrated key to the genera and subgenera of the recent azooxanthellate Scleractinia (Cnidaria, Anthozoa), with an attached glossary. ZooKeys 227:1-47

Cairns SD, Hoeksema BW, van der Land J (1999) List of extant stony corals. Atoll Res Bull 459:13-46

Calado R, Narciso L (2005) Ability of Monaco shrimp Lysmata seticaudata (Decapoda: Hippolytidae) to control the pest glass anemone Aiptasia pallida (Actiniaria: Aiptasidae). Helgol Mar Res 59:163-165

Caras T, Pasternak Z (2009) Long-term environmental impact of coral mining at the Wakatobi marine park, Indonesia. Ocean Coast Manag 52:539-544

CITES (2020) CITES Trade Database. Accessed at: https://trade.cites. org/. Accessed 29-03-2020 
Collins RA, Armstrong KF, Meier R, Yi Y, Brown SD, Cruickshank RH, Johnston C (2012) Barcoding and border biosecurity: identifying cyprinid fishes in the aquarium trade. PLoS One 7:e28381

Dawson Shepherd AR, Warwick RM, Clarke KR, Brown BE (1992) An analysis of fish community responses to coral mining in the Maldives. Environ Biol Fish 33:367-380

de Boer HJ, Ghorbani A, Manzanilla V, Raclariu A-C, Kreziou A, Ounjai S, Osathanunkul M, Gravendeel B (2017) DNA metabarcoding of orchid-derived products reveals widespread illegal orchid trade. Proc R Soc B 284:20171182

Dee LE, Horii SS, Thornbill DJ (2014) Conservation and management of ornamental coral reef wildlife: successes, shortcomings, and future directions. Biol Conserv 169:225237

Eurlings MCM, Lens F, Pakusza C, Peelen T, Wieringa JJ, Gravendeel B (2013) Forensic identification of Indian snakeroot (Benth. ex Kurz) using DNA barcoding. J Forensic Sci 58:822-830

Feitosa LM, Martins APB, Giarrizzo T, Macedo W, Monteiro IL, Gemaque R, Nunes JLS, Gomes F, Schneider H, Sampaio I, Souza R, Sales JB, Rodrigues-Filho LF, Tchaicka L, CarvalhoCosta LF, (2018) DNA-based identification reveals illegal trade of threatened shark species in a global elasmobranch conservation hotspot. Sci Rep 8:3347

Gasparini JL, Floeter SR, Ferreira CEL, Sazima I (2005) Marine ornamental trade in Brazil. Biodivers Conserv 14:2883-2899

Gathier G, Niet T, Peelen T, Vugt RR, Eurlings M, Gravendeel B (2013) Forensic identification of CITES protected slimming cactus (Hoodia) using DNA barcoding. J Forensic Sci 58:1467-1471

Gittenberger A, Reijnen BT, Hoeksema BW (2011) A molecularly based phylogeny reconstruction of mushroom corals (Scleractinia: Fungiidae) with taxonomic consequences and evolutionary implications for life history traits. Contrib Zool 80:107-132

Golbuu Y, Richmond RH (2007) Substratum preferences in planula larvae of two species of scleractinian corals, Goniastrea retiformis and Stylaraea punctata. Mar Biol 152:639-644

Gurjão LM, Lotufo TMC (2018) Native species exploited by marine aquarium trade in Brazil. Biota Neotrop 18:e20170387

Harriott VJ (2001) The sustainability of Queensland's coral harvest fishery. CRC Reef Research Centre Technical Report 40. CRC Reef Research Centre, Townsville

Hebert PD, Cywinska A, Ball SL, Dewaard JR (2003) Biological identifications through DNA barcodes. Proc R Soc Lond B 270:313-321

Hoeksema BW (2004) Mushroom corals and scleractinian genera. In: Pet-Soede L, Erdmann M (eds) Rapid Ecological Assessment Wakatobi National Park. November 2003. Directorate General of Forest Protection and Nature Conservation, Ministry of Forestry, Jakarta; Marine Program, WWF Indonesia, Bali; The Nature Conservancy. Southeast Asia Center for Marine Protected Areas, Bali, pp 67-76

Hoeksema BW (2012) Extreme morphological plasticity enables a free mode of life in Favia gravida at Ascension Island (South Atlantic). Mar Biodivers 42:289-295

Hoeksema BW, Cairns S (2018) World list of Scleractinia. Polycyathus Duncan, 1876. Accessed at: http://www.marinespecies.org/ scleractinia/aphia.php?p=taxdetails\&id $=135098$ on $16-01-2020$

Hoeksema BW, Wirtz P (2013) Over 130 years of survival by a small, isolated population of Favia gravida corals at Ascension Island (South Atlantic). Coral Reefs 32:551

Katoh K, Standley DM (2013) MAFFT multiple sequence alignment software version 7: improvements in performance and usability. Mol Biol Evol 30:772-780

Kitano YF, Benzoni F, Arrigoni R, Shirayama Y, Wallace CC, Fukami H (2014) A phylogeny of the family Poritidae (Cnidaria, Scleractinia) based on molecular and morphological analyses. PLoS One 9: e98406

Kuo CY, Chung A, Keshavmurthy S, Huang YY, Yang SY, Chen CA (2019) Lonely giant on the sand: unexpected massive Taiwanese coral, Polycyathus chaishanensis in the Datan algal reef demands a conservation focus. Galaxea J Coral Reef Stud 21:11-12

Li Y, Zheng X, Yang X, Ou D, Lin R, Liu X (2017) Effects of live rock on removal of dissolved inorganic nitrogen in coral aquaria. Acta Oceanol Sin 36:87-94

Lin M-F, Luzon KS, Licuanan WY, Ablan-Lagman MC, Chen CA (2011) Seventy-four universal primers for characterizing the complete mitochondrial genomes of scleractinian corals (Cnidaria; Anthozoa). Zool Stud 50:513-524

Lin M-F, Kitahara MV, Tachikawa H, Keshavmurthy S, Chen CA (2012) A new shallow-water species, Polycyathus chaishanensis sp. nov. (Scleractinia: Caryophylliidae), from Chaishan, Kaohsiung, Taiwan. Zool Stud 51:213-221

Liu S-YV, Chan C-LC, Lin O, Hu C-S, Chen CA (2013) DNA barcoding of shark meats identify species composition and CITES-listed species from the markets in Taiwan. PLoS One 8:e79373

Lovell ER (2001) Status report: collection of coral and other benthic reef organisms for the marine aquarium and curio trade in Fiji. World wide Fund for Nature. South Pacific Program, Suva

Morrisey D, Inglis G, Neil K, Bradley A, Fitridge I (2011) Characterization of the marine aquarium trade and management of associated marine pests in Australia, a country with stringent import biosecurity regulation. Environ Conserv 38:89-100

Padilla DK, Williams SL (2004) Beyond ballast water: aquarium and ornamental trades as sources of invasive species in aquatic ecosystems. Front Ecol Environ 2:131-138

Parks JE, Pomeroy RS, Balboa CM (2003) The economics of live rock and live coral aquaculture. In: Cati JC, Brown CL (eds) Marine ornamental species: collection, culture, and conservation. Iowa State Press, Ames, pp 185-206

Randall RH, Myers RF (1983) Guide to the coastal resources of Guam 2. The corals. University of Guam Press, Guam

Rhyne AL, Lin J, Deal KJ (2004) Biological control of aquarium pest anemone Aiptasia pallida Verrill by peppermint shrimp Lysmata risso. J Shellfish Res 23:227-229

Rhyne A, Rotjan R, Bruckner A, Tlusty M (2009) Crawling to collapse: ecologically unsound ornamental invertebrate fisheries. PLoS One 4:e8413

Rhyne AL, Tlusty MF, Kaufman L (2012) long-term trends of coral imports into the United States indicate future opportunities for ecosystem and societal benefits. Conserv Lett 5:478-485

Richards ZT, Garcia RA, Wallace CC, Rosser NL, Muir PR (2015) A diverse assemblage of reef corals thriving in a dynamic intertidal reef setting (Bonaparte Archipelago, Kimberley, Australia). PLoS ONE 10:e0117791

Simões N, Altamira A, Shei M, Perissonotti F (2017) Live rock. In: Calado R, Olivotto I, Oliver MP, Holt GJ (eds) Marine ornamental species aquaculture. Wiley-Blackwell, Hoboken, pp 385-401

Staats M, Arulandhu A, Gravendeel B, Holst-Jensen A, Scholtens I, Peelen T, Prins T, Kok E (2016) Advances in DNA metabarcoding for food and wildlife forensic species identification. Anal Bioanal Chem 408:4615-4630

Stamatakis A (2014) RAxML Version 8: a tool for phylogenetic analysis and post-analysis of large phylogenies. Bioinformatics 30:13121313

Takabayashi M, Carter DA, Loh WKT, Hoegh-Guldberg O (1998) A coral-specific primer for PCR amplification of the internal transcribed spacer region in ribosomal DNA. Mol Ecol 7:925-931

Venkataraman K (2007) Azooxanthellate hard corals (Scleractinia) from India. Bull Mar Sci 81(Suppl 1):207-214

Verheij E, Best MB (1987) Notes on the genus Polycyathus Duncan, 1876 and a description of three new scleractinian corals from the indo-Pacific. Zool Med Leiden 61:147-154

Vranken S, Bosch S, Peña V, Leliaert F, Mineur F, De Clerck O (2018) A risk assessment of aquarium trade introductions of seaweed in European waters. Biol Invasions 20:1171-1187 
Wabnitz C, Taylor M, Green E, Razak T (2003) From ocean to aquarium. UNEP-World Conservation Monitoring Centre, Cambridge

Walters LJ, Brown KR, Stam WT, Olsen JL (2006) E-commerce and Caulerpa: unregulated dispersal of invasive species. Front Ecol Environ 4:75-79

Wehr GG (2017) Alien invasive risk assessment of the marine aquarium trade in South Africa. Genome 60:1009

Wells JW (1982) Notes on Indo-Pacific scleractinian corals. Part 9. New corals from the Galápagos Islands. Pac Sci 36:211-219

White TJ, Bruns T, Lee S, Taylor J (1990) Amplification and direct sequencing of fungal ribosomal RNA genes for phylogenetics. In: Innis MA, Gelfand DH, Sninsky JJ, White TJ (eds) PCR protocols. A guide to methods and application. San Diego Academic Press Inc, San Diego, pp 315-322

Wijsman-Best M (1970) A new species of Polycyathus Duncan, 1876 from New Caledonia and a new record of Polycyathus senegalensis Chevalier, 1966 (Madreporaria). Beaufortia 17:79-84
Wood E, Malsch K, Miller J (2012) International trade in hard corals: review of management, sustainability and trends. Proc $12^{\text {th }}$ Int Coral Reef Symp 19C:1-5

Yu M, Jiao L, Guo J, Wiedenhoeft AC, He T, Jiang X, Yin Y (2017) DNA barcoding of vouchered xylarium wood specimens of nine endangered Dalbergia species. Planta 246:1165-1176

Yuen YS, Yamazaki SS, Nakamura T, Tokuda G, Yamasaki H (2009) Effects of live rock on the reef-building coral Acropora digitifera cultured with high levels of nitrogenous compounds. Aquac Eng 41: $35-43$

Publisher's note Springer Nature remains neutral with regard to jurisdictional claims in published maps and institutional affiliations. 